\title{
AN ANALYSIS OF STUDENT'S CRITICAL THINKING SKILLS IN PHYSICS LESSON IN SMA 8 PEKANBARU
}

\author{
Afrima Nori $^{{ }^{* 1}}$, Zulirfan ${ }^{2)}$, Zuhdi Ma'aruf $^{3)}$ \\ ${ }^{1,2,3)}$ Physics Education, University of Riau \\ e-mail: afrimanori@gmail.com \\ zirfanaziz69@gmail.com \\ zuhdim@yahoo.co.id
}

\begin{abstract}
Critical thinking ability is one of the high-level thinking skills that are problem solving skills essentially. The main purpose of this research is to describe the level of students' critical thinking skills in physics subjects at SMAN 8 Pekanbaru. The population in the study were 316 students of grade 11 of SMAN 8 Pekanbaru. Samples were taken by purposive sampling so that a sample of 33 students. The instrument of this research is a test of critical thinking skills which is based on 12 indicators of critical thinking skills. Data was collected by giving a test of critical thinking skills to the sample. Data analysis in this study used descriptive, which provide an overview of the level of critical thinking skills. The results of this study provide information that the average percentage of critical thinking skills students of SMAN 8 Pekanbaru is 50.88\% with a moderate level of critical thinking ability.
\end{abstract}

Keywords: critical thinking ability, physics lesson, descriptive analysis.

\section{ANALISIS KEMAMPUAN BERPIKIR KRITIS PESERTA DIDIK PADA MATA PELAJARAN FISIKA DI SMAN 8 PEKANBARU}

\author{
Afrima Nori ${ }^{* 1)}$, Zulirfan $^{2)}$, Zuhdi Ma'aruf $^{3)}$ \\ ${ }^{1,2,3)}$ Pendidikan Fisika, Universitas Riau
}

\begin{abstract}
Abstrak
Kemampuan berpikir kritis adalah salah satu keterampilan berpikir tingkat tinggi yang secara esensial merupakan keterampilan menyelesaikan masalah (problem solving). Tujuan utama penelitian ini adalah mendeskripsikan tingkat kemampuan berpikir kritis peserta didik pada mata pelajaran fisika di SMAN 8 Pekanbaru. Pada penelitian ini populasinya adalah 316 peserta didik kelas XI SMAN 8 Pekanbaru. Sampel diambil secara purposive sampling sehingga diperoleh sampel berjumlah 36 peserta didik. Instrumen penelitian ini berupa soal tes kemampuan berpikir kritis yang disusun berdasarkan indikator berpikir kritis. Data dikumpulkan dengan cara memberikan tes kemampuan berpikir kritis kepada sampel. Analisis data pada penelitian ini menggunakan analisis deskriptif dengan teknik presentase, yang memberikan gambaran tentang tingkat kemampuan berpikir kritis. Hasil penelitian ini memberikan informasi bahwa persentase rata-rata kemampuan berpikir kritis peserta didik SMAN 8 Pekanbaru sebesar 50,88\% dengan tingkat kemampuan berpikir kritis sedang.
\end{abstract}

Kata Kunci: kemampuan berpikir kritis, pelajaran fisika, analisis deskriptif

\footnotetext{
${ }^{* 1)}$ Komunikasi Penulis
} 


\section{Pendahuluan}

Menurut Suyono dan Hariyanto (dalam Nurul et al., 2014) kecakapan hidup atau life skills adalah keahlian atau keterampilan yang harus dimiliki oleh setiap individu untuk mengatasi setiap masalah yang dihadapi dalam menjalani kehidupan di masyarakat, kemudian secara proaktif dan kreatif mencari serta menemukan solusi untuk mengatasinya. Secara umum kecakapan hidup diklasifikasikan menjadi empat jenis, yaitu: (a) kecakapan personal (personal skill) yang mencangkup kecakapan mengenal diri (self awareness) dan kecakapan berpikir (thinking skill), (b) kecakapan sosial (social skill), (c) kecakapan akademik (academic skill), dan (d) kecakapan vokasional (vocational skill).

Kecakapan-kecakapan yang telah disebutkan tersebut merupakan faktor pendorong untuk membentuk kepribadian peserta didik, terutama kecapakan hidup yang pada saat ini harus ditanamkan kepada peserta didik adalah kecakapan berpikir atau kemampuan berpikir. Kemampuan berpikir ini tidak hanya menitik beratkan pada penguasaan materi, namun mendukung pada kemampuan berkomunikasi, berpikir kreatif, berpikir jernih, dan berpikir kritis.

Keterampilan berpikir kritis termasuk salah satu keterampilan berpikir tingkat tinggi yang secara esensial merupakan keterampilan menyelesaikan masalah (problem solving). Selain itu, berpikir kritis merupakan dasar untuk belajar mendalam dan terintegrasi. Tanpa berpikir kritis, peserta didik tidak dapat mempelajari sesuatu dengan cara yang lebih bermakna, serta tidak bisa belajar lebih mendalam untuk mengembangkan dan memajukan pemikiran (Dede Trie Kurniawan, 2017).

Jika dilihat dari pencapaian Indonesia, beberapa tahun berturut-turut peringkat Indonesia dalam Human Development Index (HDI) menempati posisi pada urutan bawah, dimana Indonesia pada tahun 2006 berada pada posisi 108 dari 177 negara. Hal tersebut menunjukkan rendahnya kualitas sumber daya manusia Indonesia yang menandakan lemahnya sistem pendidikan di Indonesia. Akibatnya sumber daya manusia (SDM) yang dihasilkan adalah generasi yang kurang percaya diri, kurang bisa bekerja, kurang terampil dan kurang berkarakter. Maka tidak heran jika mutu SDM Indonesia dalam HDI berada jauh di bawah Malaysia, Thailand, Filipina, dan terutama Singapura yang telah masuk dalam kategori high human development (Dede \& Nurdin, 2013). Oleh karena itu, upaya mempercepat peningkatan kualitas pendidikan tidak ada jalan lain yang dapat dilakukan selain harus dimulai melalui kegiatan penelitian (Mulyasa, 2012).

Beberapa penelitian telah dilakukan untuk mengetahui tingkat kemapuan berpikir kritis, seperti yang dilakukan oleh Wahyu \& Fikri (2018) diperoleh hasil bahwa kemampuan berpikir kritis peserta didik SMA N 4 Lubuklinggau Sumatera Selatan kelas $\mathrm{X}_{4}$ berada pada kategori rendah. Hasil penelitian lain yang dilakukan oleh Ayu Lingga Ratna Sari et al., (2016) mendapatkan kesimpulan bahwa kemampuan berpikir kritis dan pemahaman konsep fisika peserta didik pada materi hukum Newton rendah. Penelitian ini dilakukan dengan maksud agar kita dapat mengetahui penyebab dari masalah yang terjadi dibidang pendidikan khususnya pada kemampuan berpikir peserta didik.

SMAN 8 Pekanbaru adalah salah satu SMA Negeri dengan prestasi akademik bagus di Provinsi Riau. Sekolah ini termasuk sekolah peyelenggara akselerasi semenjak tahun 2001 sampai dengan sekarang. Berbagai prestasi terutama dibidang akademik menjadikan SMAN 8 Pekanbaru sebagai sekolah favorit di Riau. Prestasi ini tentu tidak lepas dari proses pembelajaran dan fasilitas yang ada di SMAN 8 Pekanbaru. Kemampuan akademik yang bagus sering dianggap sebagai kemampuan berpikir yang bagus yaitu salah satunya kemampuan berpikir kritis. Kemampuan berpikir kritis peserta didik pada mata pelajaran fisika di SMAN 8 Pekanbaru merupakan tujuan utama penelitian ini.

\section{Bahan dan Metode}

Penelitian dilakukan di SMAN 8 Pekanbaru yang telah menerapkan Kurikulum 2013. Pada penelitian ini populasinya adalah peserta didik kelas XI SMAN 8 Pekanbaru yang terdiri dari 9 kelas dengan jumlah 316 peserta didik. Semua kelas MIA memiliki jumlah peserta didik dengan rata-rata yang sama, sehingga diambil kelas XI MIA 2 sebagai sampel dengan teknik purposive sampling. 
Jenis penelitian ini adalah penelitian survei. Penelitian dilakukan dengan mengambil informasi atau data secara langsung terhadap subjek penelitian. Instrumen yang digunakan adalah soal tes kemampuan berpikir kritis berupa 24 soal objektif dengan empat pilihan jawaban. Tes tersebut disusun berdasarkan indikator kemampuan berpikir kritis yang diadaptasi dari (Ennis, 2011).

Tabel 1. Kategori tingkat berpikir kritis peserta didik

\begin{tabular}{ccl}
\hline No & $\begin{array}{c}\text { Persentase } \\
\text { Pencapaian (\%) }\end{array}$ & \multicolumn{1}{c}{ Kategori } \\
\hline 1. & $80<N \leq 100$ & Sangat Tinggi \\
2. & $60<N \leq 80$ & Tinggi \\
3. & $40<N \leq 60$ & Sedang \\
4. & $20<N \leq 40$ & Rendah \\
5. & $0<N \leq 20$ & Sangat Rendah \\
\hline
\end{tabular}

Teknik analisis data pada penelitian ini adalah analisis deskriptif, analisis deskriptif dalam penelitian digunakan untuk memberikan gambaran tentang kemampuan berpikir kritis peserta didik. Peneliti menggunakan kategori tingkat berpikir kritis peserta didik yang dikembangkan oleh Setyowati (dalam Wahyu \& Fikri, 2018) seperti pada Tabel 1.

Kriteria penarikan kesimpulan dalam penelitian ini dapat dinyatakan memiliki kemampuan berpikir kritis yang baik jika mampu menjawab soal tes yang diberikan dan tergolong dalam kategori tinggi dan sangat tinggi.

\section{Hasil dan Pembahasan}

Distribusi jawaban peserta didik pada penelitian ini ditabulasikan. Jawaban ini kemudian diinterpretasikan dan dianalisis ratarata persentase kemampuan berpikir kritis setiap soal, setiap indikator dan rata-rata persentase secara keseluruhan menggunakan rumus yang telah ditentukan. Data dikelompokkan menjadi 5 kategori yaitu sangat tinggi, tinggi, sedang, rendah, dan sangat rendah. Berdasarkan hasil pengolahan diperoleh persentase kemampuan berpikir kritis peserta didik pada masing-masing aspek dan indikator sebagaimana terlihat pada Tabel 2.

Berdasarkan Tabel 2 dapat dilihat bahwa rata-rata kemampuan berpikir kritis peserta didik adalah 50,88\% dengan kategori sedang. Aspek menyimpulkan memiliki persentase paling tinggi yaitu $61,11 \%$ dengan kategori tinggi. Sedangkan aspek mengatur strategi dan taktik memiliki persentase paling rendah yaitu $42,42 \%$ dengan kategori sedang. Secara keseluruhan kemampuan berpikir kritis peserta didik sudah memiliki tingkat kemampuan berpikir kritis yang cukup baik.

\section{Memberikan penjelasan sederhana}

Melalui aspek ini peserta didik mengalami proses memfokuskan pertanyaan dan menganalisis argumen dengan menyelidiki suatu alasan untuk mengetahui keadaan sebenarnya. Johnson mengatakan "pemikir kritis meneliti proses berpikir mereka sendiri dan proses berpikir orang lain untuk mengetahui apakah proses berpikir mereka masuk akal". Proses dialeksi dalam otak yang dilakukan peserta didik menjadikan peserta didik berpikir, membaca suatu pendapat dan menterjemahkan dengan bahasanya masingmasing untuk dapat menjelaskan secara sederhana apa yang mereka ketahui secara tertulis (Ihwan Rizky, 2014). Persentase keterampilan berpikir kritis peserta didik pada masing-masing indikator atau nomor soal dapat dilihat dari grafik pada Gambar 1.

Berdasarkan grafik pada Gambar 1 persentase keterampilan memberikan penjelasan sederhana tertinggi pada nomor 6 , sub indikator memberikan contoh sebesar $72,73 \%$. Sedangkan persentase keterampilan memberikan penjelasan sederhana terendah pada nomor 5, sub indikator memberikan penjelasan sederhana sebesar 3,03\%. 
Tabel 2. Persentase rata-rata kemampuan berpikir kritis peserta didik per aspek

\begin{tabular}{|c|c|c|c|c|}
\hline No & Aspek & Indikator & $\begin{array}{l}\text { Rata-rata } \\
(\%)\end{array}$ & Kategori \\
\hline 1. & $\begin{array}{l}\text { Memberikan penjelasan } \\
\text { sederhana }\end{array}$ & $\begin{array}{l}\text { 1. Memfokuskan pertanyaan } \\
\text { 2. Menganalisis argumen } \\
\text { 3. Bertanya dan menjawab } \\
\text { pertanyaan }\end{array}$ & 47,47 & Sedang \\
\hline 2. & $\begin{array}{l}\text { Membangun } \\
\text { keterampilan dasar }\end{array}$ & $\begin{array}{l}\text { 4. Mempertimbangkan apakah } \\
\text { sumber dapat dipercaya atau } \\
\text { tidak } \\
\text { 5. Mengobservasi dan } \\
\text { mempertimbangkan laporan } \\
\text { observasi }\end{array}$ & 54,55 & Sedang \\
\hline 3. & Menyimpulkan & $\begin{array}{l}\text { 6. Mendeduksi dan } \\
\text { mempertimbangkan hasil } \\
\text { deduksi } \\
\text { 7. Menginduksi dan } \\
\text { mempertimbangkan hasil } \\
\text { induksi } \\
\text { 8. Membuat dan menentukan hasil } \\
\text { pertimbangan }\end{array}$ & 61,11 & Tinggi \\
\hline 4. & $\begin{array}{l}\text { Memberikan penjelasan } \\
\text { lanjut }\end{array}$ & $\begin{array}{l}\text { 9. Mendefinisikan istilah dan } \\
\text { mempertimbangkan suatu } \\
\text { definisi } \\
\text { 10. Mengidentifikasi asumsi- } \\
\text { asumsi }\end{array}$ & 45,45 & Sedang \\
\hline 5. & $\begin{array}{l}\text { Mengatur strategi dan } \\
\text { taktik }\end{array}$ & $\begin{array}{l}\text { 11. Menentukan suatu tindakan } \\
\text { 12. Berinteraksi dengan orang lain }\end{array}$ & 42,42 & Sedang \\
\hline \multicolumn{3}{|c|}{ Rata-rata persentase keseluruhan } & 50,88 & Sedang \\
\hline
\end{tabular}

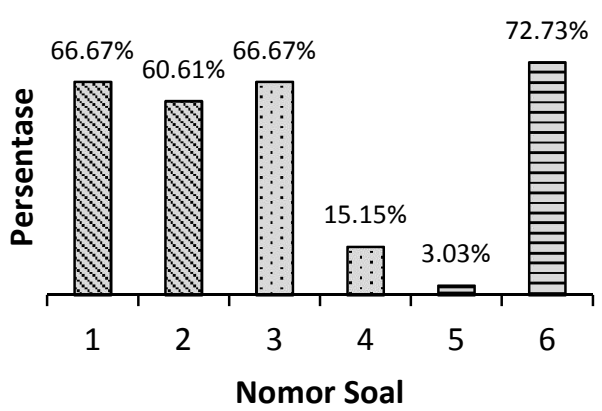

W Memfokuskan pertanyaan

$\therefore \quad$ Menganalisis argumen

Bertanya dan menjawab

Gambar 1. Persentase aspek memberikan penjelasan sederhana.

\section{Membangun keterampilan dasar}

Aspek ini meminta peserta didik mengobservasi dan mempertimbangkan hasil observasi yang dilakukan. Berpikir kritis mengarahkan peserta didik untuk melangkah keluar dari hal-hal menipu diri sendiri dengan melihat langsung hal-hal tersebut dari berbagai sudut dan kemudian mengevaluasinya melalui proses kegiatan intelektual yang ketat. Kegiatan intelektual yang ketat merupakan observasi dan pengukuran terhadap fenomena yang terjadi. Kegiatan tersebut dapat menghasilkan bukti secara empiris, tergantung pada percobaan atau eksperimen yang berakal dari pengalaman dari dunia nyata dari objek yang ada dalam ruang dan waktu (Ika Rahmawati et al., 2016). Persentase keterampilan berpikir kritis peserta didik pada masing-masing indikator atau nomor soal dapat dilihat dari grafik pada Gambar 2. 


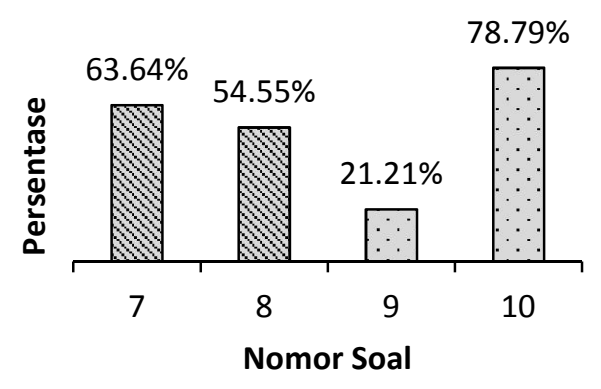

Mempertimbangkan apakah sumber dapat dipercaya atau tidak

Mengobservasi dan mempertimbangkan laporan observasi

Gambar 2. Persentase aspek membangun keterampilan dasar.

Berdasarkan grafik pada Gambar 2 persentase keterampilan membangun keterampilan dasar tertinggi pada nomor 10 , sub indikator melaporkan hasil observasi sebesar 78,79\%. Sedangkan persentase keterampilan membangun keterampilan dasar terendah pada nomor 9, sub indikator melibatkan sedikit dugaan sebesar 21,21\%.

\section{Menyimpulkan}

Membuat kesimpulan berarti mengidentifikasi unsur yang diperlukan untuk menarik kesimpulan dari data, laporan, prinsip, penilaian, keyakinan atau pendapat dan penalaran. Penalaran deduktif mengacu pada kesimpulan dari umum ke khusus dan keterampilan induktif merujuk untuk kesimpulan dari khusus ke umum (Ika Rahmawati, 2016). Persentase keterampilan berpikir kritis peserta didik pada masingmasing indikator atau nomor soal dapat dilihat dari grafik pada Gambar 3.

Berdasarkan grafik pada Gambar 3 persentase keterampilan menyimpulkan tertinggi pada nomor 12, sub indikator menyatakan tafsiran sebesar $75,76 \%$. Sedangkan persentase keterampilan menyimpulkan terendah pada nomor 11 , sub indikator mengkondisikan logika sebesar $33,33 \%$.

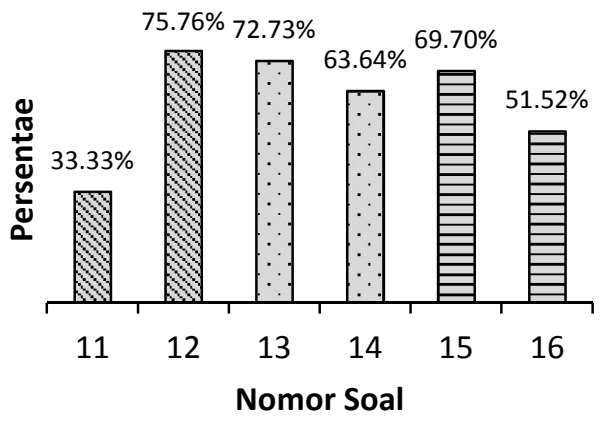

Mendeduksi dan mempertimbangkan hasil deduksi

Menginduksi dan mempertimbangkan hasil induksi dan membuat

Menentukan hasil pertimbangan

Gambar 3. Persentase aspek menyimpulkan.

\section{Memberikan Penjelasan Lanjut}

Pada aspek ini, peneliti menganalisis indikator keterampilan berpikir kritis dalam memahami arti dari sebuah istilah untuk menjadi pengalaman lebih lanjut. Pada aspek ini peserta didik harus mengidentifikasi asumsi-asumsi dengan mengkonstruk sebuah argumen karena sebuah asumsi baru bisa diterima apabila jelas, logis, dan didasarkan pada pengalaman yang luas (Ihwan Riski, 2014). Persentase keterampilan berpikir kritis peserta didik pada masing-masing indikator atau nomor soal dapat dilihat dari grafik pada Gambar 4.

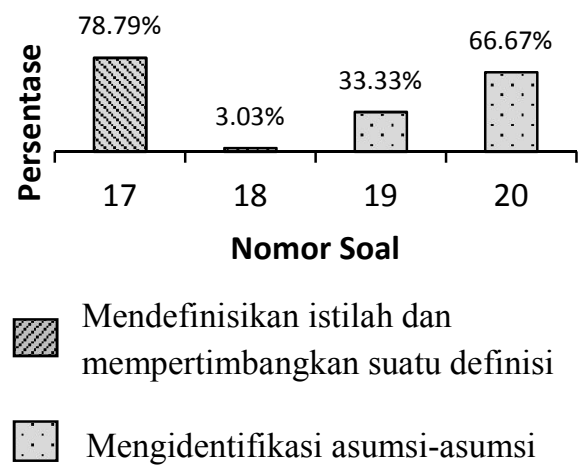

Gambar 4. Persentase aspek memberikan penjelasan lanjut. 
Berdasarkan grafik pada Gambar 4 persentase keterampilan memberikan penjelasan lanjut tertinggi pada nomor 17, sub indikator membuat bentuk definisi sebesar 78,79\%. Hasil tersebut relevan kajian Azizah et al., (2018) yang menganalisis keterampilan berfikir kritis peserta didik di Sekolah Dasar. Sedangkan persentase keterampilan memberikan penjelasan lanjut terendah pada nomor 18, sub indikator mengidentifikasi dan menangani ketidakbenaran yang disengaja sebesar $3,03 \%$.

\section{Mengatur strategi dan taktik}

Aspek kelima ini, peserta didik memutuskan suatu tindakan dengan mempertimbangkan solusi yang mungkin dari apa yang mereka sedang hadapi. Peserta didik melakukan berdasarkan informasi dan pengalaman yang telah dimiliki dari interaksi kehidupan sehari-hari. Sehingga peserta didik dapat menghasilkan keputusan yang sangat baik dan peserta didik ada pada sepenuh rasa untuk meyakini sebuah hasil dan menetapkannya dalam sebuah tindakan (Ihwan Riski, 2014). Persentase keterampilan berpikir kritis peserta didik pada masing-masing indikator atau nomor soal dapat dilihat dari grafik pada Gambar 5.

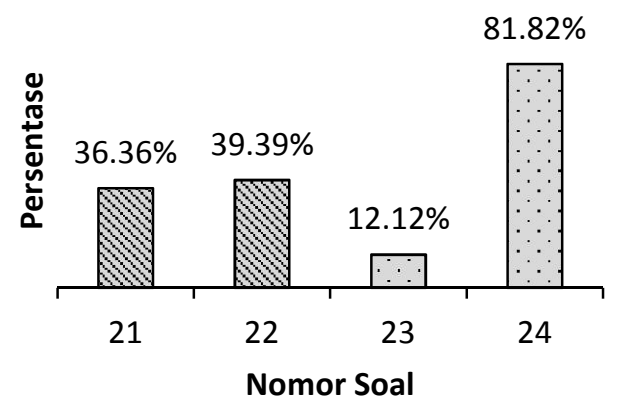

\# Menentukan suatu tindakan

Berinteraksi dengan orang lain

Gambar 5. Persentase aspek mengatur strategi dan taktik.

Berdasarkan grafik pada Gambar 5 persentase keterampilan mengatur strategi dan taktik tertinggi pada nomor 24, sub indikator berinteraksi dengan orang lain yaitu $81,82 \%$. Sedangkan persentase keterampilan lanjut mengatur strategi dan taktik terendah pada nomor 23, sub indikator menggunakan strategi logika sebesar $12,12 \%$.

\section{Kesimpulan dan Saran}

Kemampuan berpikir kritis peserta didik SMAN 8 Pekanbaru masih berada pada kategori sedang. Persentase rata-rata kemampuan berpikir kritis peserta didik untuk setiap aspek dan indikator keterampilan berpikir kritis, yakni untuk aspek memberikan penjelasan sederhana kategori sedang, masih tergolong setengah dari peserta didik yang memahami keterampilan ini.

Berdasarkan simpulan tersebut, maka direkomendasikan agar guru dapat lebih kreatif dalam merancang dan mengembangkan perangkat pembelajaran agar mampu meningkatkan kemampuan berpikir kritis peserta didik, sehingga menjadi habit. Pembelajaran fisika untuk peserta didik juga diharapkan lebih menekankan kepada contohcontoh aplikasi fisika didalam kehidupan sehari-hari. Untuk pengkajian lanjutan, supaya dapat meneruskan kajian dengan melaksanakan penelitian eksperimen agar mengatasi kurangnya kemampuan berpikir kritis peserta didik.

\section{Daftar Pustaka}

Ayu Lingga Ratna Sari, Parno, \& Ahmad Taufiq, 2016. Kemampuan Berpikir Kritis dan Pemahaman Konsep Fisika Peserta didik SMA pada Materi Hukum Newton, Pros. Semnas IPA Pasca sarjana UM, Vol 1(97). http://pasca. um.ac.id (diakses 11 Desember 2018).

Dede Parsaoran Damanik \& Nurdin Bukit, 2013. Analisis Kemampuan Berpikir Kritis dan Sikap Ilmiah pada Pembelajaran Fisika Menggunakan Model Pembelajaran Inquiry Training (IT) dan Direct Instruction (DI). Jurnal Pendidikan Fisika, Vol. 2(1). ISSN: 23017651.

Dede Trie Kurniawan, Nelli Ma'rifat Sanusi, \& Nurul Ikhsan Karimah, 2017. Pembelajaran Konsep Mekanika Fluida Statis Berbantuan Praktikum Virtual dalam Mengembangkan Keterampilan 
Berpikir Kritis Mahasiswa Calon Guru Matematika. Phenomenon, 2017, Vol. 07 (No. 2), pp. 110-11.

Ennis, R., 2011. Inquiry: Critical Thinking Across the Disciplines, 26 (2):5-19.

Ika Rahmawati, Arif Hidayat, \& Sri Rahayu, 2016. Analisis Kemampuan Berpikir kritis Siswa Pada Materi Gaya dan Penerapannya, Pros. Semnas Pend. IPA Pascasarjana UM, Vol 1. http://pasca. um.ac.id (diakses 10 Maret 2019).

Ihwan Rizky, 2014. Analisis Keterampilan Berpikir Kritis Siswa dengan Menggunakan Media Pembelajaran (Video) pada Materi Minyak Bumi. Skripsi, Fitk Universitas Islam Negeri Syarif Hidayatullah, Jakarta.

Mira Azizah, Joko Sulianto, \& Nyai Cintang, 2018. Analisis Keterampilan Berpikir Kritis Siswa Sekolah Dasar pada
Pembelajaran Matematika Kurikulum 2013. Jurnal Penelitian Pendidikan, http://journal.unnes.ac.id (diakses 14 Maret 2019).

Mulyasa, 2012. Penelitian Tindakan Sekolah. PT Remaja Rosdakarya, Bandung.

Nurul, M. Karimah, Endang Susantini, \& Nur Kuswanti, 2014. Penerapan LKS Berorientasi Life Skill Terhadap Hasil Belajar Siswa Kelas XI SMA pada Materi Sistem Peredaran Darah. Bio Edul, Vol 3 (1). ISSN: 2302-9538.

Wahyu Arini \& Fikri Juliadi, 2018. Analisis Kemampuan Berpikir Kritis pada Mata Pelajarn Fisika untuk Pokok Bahasan Vektor Siswa Kelas X SMA Negeri 4 Lubuklinggau, Sumatera Selatan, Berkala Fisika Indonesia, Volime 10 (1):10. (Online). www.journal.uad.ac.id (diakses 1 Maret 2019). 